\title{
Research on Comparison between Government of Enterprise and
}

\section{Government of Service}

\author{
Jin $\operatorname{Lan}^{1}$ \\ ${ }^{1}$ School of Literature, Law and Economics, Wuhan University of Science and Technology, Wuhan, \\ Hubei, China, 430065
}

Keywords: Government of Enterprise, Government of Service, Efficiency, Fairness

\begin{abstract}
Under the background of economic globalization and political democratization, the entrepreneurial government has effectively changed the traditional government's management system. Under the background of comprehensively deepening political reform and promoting the modernization in governing system and capability, China will continue to strengthen the construction of service oriented government.This paper mainly compares the government reform models of China's service-oriented government and western entrepreneurial government and summarizes their commonalities, differences, advantages and disadvantages to provide some references for the improvement of China's service-oriented government.

The advent of the information age requires the change and adjustment of the organization and operation of the process of the government to solve the crisis of the decline of government credibility, low efficiency ofpublic management and service. However, due to the strict rank system and administrative structure defects, the traditional bureaucratic governmentcannot meet the new demand of contemporary government. The government of enterprise and the government of service were born. What follows in this paper will compare the two types of government, explore the commonalities, differences, advantages and disadvantages and provide some suggestions for the improvement of the service oriented government of our country.
\end{abstract}

\section{Connotation of Government of Enterprise and Government of Service}

The theory of entrepreneurial government came from the two concepts of "entrepreneur" and "entrepreneurship". Scholar Drucker believed that entrepreneurship is not limited in the economic organizations, but also can be applied in government departments. American scholar Osborne and Gaebler formally proposed the concept of entrepreneurial government. His view can be summarized as the following several points: the function of government is steering, not padding; the government does not have to take care of every single thing personally. The government need delegate and introduce public participation and market competition mechanism; the government should concern the public needs, and stress the importance of the results assessment; the government should introduce incentive mechanism. The government should also have the spirit of innovation.In short, entrepreneurial government should absorb the experience of business management and entrepreneurship to enhance government administration or service level to get rid of the management, trust and financial crisis. The government of enterprise will be a government of response and prediction. The three basic meanings of it are the guidance of public, the reduction of administrative costs and the advantages of competence. 
As the government of enterprise stresses the efficiency too much and ignores the fairness to some degree, the western scholars launched a "new public service theory" research. For example, the American public administration scholar named Denhardt emphasized the intention of citizens, and believed the government's main function was service. With the transmission of thetheory in China, Chinese scholars put forward the concept of "service-oriented government". Zhang Kangzhibelieved that the service-oriented government is the governmentto serve the people. Professor Liu Xiruibelieved that service-oriented governmentshould put public service first and advocate the public-oriented and society-oriented ideas. In short, under the guidance of the public-oriented and society-oriented concept, the service-oriented governmentis the government model whichfocuses the public service. The best way to distinguish between a service-oriented government and a non-service-oriented government is to investigate whether the bulk of government's financial expenditure is applied in the field of public service. Service oriented government advocates fairness, and strive to establish the fair, equitable, moderate and sustainable public service system which benefits the whole people to achieve equalization of public service.

\section{Commonalities and Differences of Entrepreneurial Government and Service Oriented Government}

The entrepreneurial government and the service-oriented government are the government's reform model to solve the crisis of finance, management and trust of the contemporary government. The two types of government have the following commonalities:

Firstly, both of them have a core idea: the public standard. Both the entrepreneurial government and the service-oriented governmentadvocate change the idea of"official standard" of traditional bureaucracy government. They stress the supremacy of the public interests, advocating citizen and society standard. The will of the citizens plays the dominant role rather than the wishes of the government in the process of public management and government service. Both of them strive to establish a new interactive relationship of trust and equality between the government and the citizens.

Secondly, in terms of the functions of the government, both of them advocate to establish the reasonable decentralization and delegation. The government will change the image of the "strong government", implementing limited administration to make the function, power and size of the government be effectivelyrestricted by laws and society.

Thirdly, in the aspect of administrative organization structure, both of them emphasize the flattening organization structure. The entrepreneurial government and the service-oriented government will break the traditional government strict hierarchy, minimize the intermediate level,and compress the organization structureto the shorten distance between the top and the base. The two models will broaden the channels of communication of the government and the ordinary people, making the government havemore affinity.

First of all, the theoretical bases are different. The entrepreneurial government advocates making use of the entrepreneurship to reform the government. However, the service oriented government is guided by the "new public service theory", which emphasizes the government's service function.

Secondly, the main functions of thegovernment are different. The dominant function of entrepreneurial government is steering, while the leading function of the service oriented government is service. Government of enterprisestresses that the government does not have pad. Service oriented government focuses the service functions and believes the national development achievement should be shared by the public. 
Thirdly, the government behavior patterns are different. Entrepreneurial government focuses on cost management, quality management, customer orientation consciousness and guidance of multiplesupplies of market participants. However, the service oriented governmentmainly provides public services and productsto help citizens to express and realize the common interests.

Fourthly, the government of enterprise pays more attention to the efficiency, while the service oriented government pays more attention to the fairness. The entrepreneurial government often set the indicators related to the economic benefits as the management goal, such as the input-output ratio. However, the service-oriented government is more focused on maintaining social fairness, coordinating the relationship between the government and the public and the relationship between different interest groups.

\section{Advantages and Disadvantages of Entrepreneurial Government and Service Oriented Government}

First, compared to the entrepreneurial government, the service-oriented government has more fairness. In the guidance of the spirit of entrepreneurs, the entrepreneurial governmentinevitably lack of some fairness in the process of the management of public affairs and public service. Some grassroots levels and ruralregions cannot enjoy part of the public service.

Second, the service government is closer to the actual conditions in China. China is a socialist state of the people. The purpose of the Communist Party is "wholeheartedly serve the people", which determinesthe main function of our government. China is abolishing dual-structure society of rural and urban areas and narrowing the economic development gap between the coastal provinces and inland provinces. The problem needing to be urgently solved is fairness, not efficiency.

First, service-oriented government also stresses the flat organization structure. However, the government of our country has too many administrative levels and institutions, which leads to low efficiency. China's current administrative organization has five levels from the central government to local government. They are the government of province, the government of city, the government of county and the government of town. Australia, Japan and the United States have only two or three levels. Too many administrative levels reduce the information speed, which is not conductive to decrease the management cost and improve administrative efficiency.

Second, compared to the entrepreneurial government, our government has a high degree of monopoly and lacks of competition. The public sectors of our country have been implementing the state monopoly for a long time. The private enterprises and other non-governmental organization cannot participate in the public service. The deficiency of accounting and supervision of input and output is everywhere in each department. Due to the monopoly in the market, the public's interests cannot be protected well.

Third, compared to the western developed countries, China's government support of the development of non-governmental organizations is obviously backward. There were 606,000 social organizations in China by the end of 2014. The total number of social organizations in the United States in 1995 was more than 1 million. The shrinkingphenomenon of social organizations is not conducive to transformation of China's government functions and improvement of public servicesquality.

\section{Enlightenment of Western Entrepreneurial Government to China's Service-Oriented Government}


The service-oriented government in China is still in construction. The above disadvantages are the focus of the reforms. We learn from the experiences of western entrepreneurial governments to put forward the following several suggestions.

In terms of administrative functions, our government should implement the limited administration to reduce administrative scale and improve administrative efficiency. We speed up government institutions reforms, reduce the management levels, decrease the human resources cost to establish a dynamic and efficient administrative management team.In the process of government public service, we should clarify the responsibilities and improve the operational efficiency of various departments in the government. In the process of the implementation of government public projects, the professional departments and expertsshouldevaluate the benefit and cost carefully. The government should also implement departmental budget renovation, centralized purchasing management and unified price settlements to reduce waste and curb corruption.

First, we should introduce the competition mechanisms in the field of providing government services. The introduction of private capital into public services will change the original phenomenon of government swept all public service, reduce the service cost and improve service efficiency. Government can outsource some public service projects to private producers with responsibility supervision, service standards and financial subsidiesto ensure the smooth development of public service. Or the government can set up two or more than two institutions to provide the same public service so that they can compete with each other to improve service efficiency and quality.

Second, we also should introduce competition mechanisms inside the government. The inside competition mechanisms include the competition of government departments and the competition of posts in government departments. We select the best qualified for the job by the timing assessment to provide a solid foundation for building a service-oriented government in China.

Benefiting from the entrepreneurial government experience,our country should use the appropriate tax and welfare policies to support the social development organizations. The social organizations with strong public welfare characteristics, such as environmental protection organizations and charitable organizations, shall be exempted from income tax and business tax. The organizations with ordinary public welfare characteristics, such as the chambers of commerce, shall be applied the tax relief policies. Through the policy support, the government promotes the growth of social organizations to realize the marketization and socialization of some of the functions of the government. It will optimize the interaction and cooperation of the government and society and the government and citizens to ultimately improve the diversified supply mechanism of public goods and servicesultimately realize the goal of the equalization of public services.

\section{References}

[1] Peter F. Drucker, Innovation and Entrepreneurship, M., China Machine Press, 2007

[2] Sun Xueyu, Semantic Interpretation and Definition of Entrepreneurial Government, J., Journal of Jiangsu Administration Institute, 2003(2): 100-105

[3] Robert B. Denhardt, Janet V.Denhardt, The New Public Service:Serving,Not Steering, M., China Renmin University Press, 2004

[4] Sun Xueyu, On Entrepreneurial Government, M., Social Sciences Academic Press, 2013 